\title{
Sınıf Öğretmenlerinin ve Sınıf Öğretmeni Adaylarının Sosyal Değerlerinin Incelenmesi ve Karşılaştırılması ${ }^{1}$
}

\section{Examination and Comparison of Social Values of Primary School Teachers and Pre-Service Teachers}

\section{Doç. Dr. Vedat AKTEPE ${ }^{2}$ - Beyza HOCAOĞULLARI - Büşra PINARBAŞI ${ }^{4}$}

Başvuru Tarihi: 23.06.2020

Kabul Tarihi: 16.09 .2020

Makale Türü: Araştırma Makalesi

Öz

Araştırmacının amacı, sını öğretmenlerinin ve sını öğretmeni adaylarının sosyal değerlerini belirlemek ve karşılaştırmaktır. Ayrıca öğretmenlerin cinsiyetlerine ve kıdemlerine göre, adayların ise cinsiyetleri ve sinıf seviyelerine göre sosyal değerlerinin farklılik gösterip göstermediğini tespit etmek amaçlanmıştır. Araştırmada var olan durumu belirlemek için betimsel araştırma modeli kullanılmıştır. Araştırmanın çalışma grubunu, Nevşehir Milli Eğitim Müdürlüğüne bağlı ilkokullarda görev yapan 343 sını öğretmeni ve Nevşehir Hacı Bektaş Veli Üniversitesi Eğitim Fakültesinde okuyan 250 sınıf öğretmeni adayı oluşturmaktadır. Araştırmanın verilerini elde etmede, 'Çok Boyutlu Sosyal Değerler Ölçeği' kullanılmış, veriler bilgisayar ortamında analiz edilmiştir. Araştırmanın alt problemleri doğrultusunda toplanan verilerin analizinde Bağımsız Örneklemler t-testi (İndependent Sample t-testi), Mann-Whitney U Testi, Tek Yönlü Varyans Analizi (One - Way ANOVA) ve Kruskal- Wallis Testi kullanılmıştır. Araştırma sonucunda, sınıf öğretmenlerinin sosyal değerleri ile sını öğretmeni adaylarının sosyal değerlerinin en yüksek ve en düşük sosyal değer ifadeleri benzerlik göstermektedir. Bu bağlamda en yüksek düzeyde "Ailemdeki bireylere büyük önem veririm." ve "Bizi yaratan bir yaratıcı olduğuna inanırım.", en düşük düzeyde ise "Dini inanışlarım hayatta karşılaştı̆̆ım olaylar üzerinde büyük etkiye sahiptir." ifadeleri olmuştur. Sınıf öğretmenlerinin ve sınıf öğretmeni adaylarının sosyal değerlerinin farklılaşıp farklılaşmadığına bakıldığında ise sınıf öğretmeni adaylarının sosyal değer puan ortalamalarının daha yüksek olduğu görülse de anlamlı derecede farklılık bulunmamıştır.

Anahtar Kelimeler: Sınıf Öğretmeni ve Öğretmen Adayları, Değer, Sosyal Değerler, Cinsiyet, Kıdem, Sınıf Düzeyi

\footnotetext{
${ }^{1}$ Nevşehir Hacı Bektaş Veli Üniversitesi Etik Kurul Komisyonundan E.7293.sayılı “Etik Kurul Belgesi” alınmıştır.

${ }^{2}$ Nevşehir Hacı Bektaş Veli Üniversitesi, Temel Eğitim Bölümü, vedataktepe@nevsehir.edu.tr, ORCID: 0000-0001-5259-9340

${ }^{3}$ Nevşehir Hacı Bektaş Veli Üniversitesi, Temel Eğitim Bölümü, beyzahocaogullari@icloud.com, ORCID: 0000-0002-9691-3861

${ }^{4}$ Nevşehir Hacı Bektaş Veli Üniversitesi, Temel Eğitim Bölümü, busrapinarbasio0@gmail.com, ORCID: 0000-0001-7133-206X
} 


\section{Abstract}

The aim of this research is to examine and compare the social values of primary school teachers and pre-service teachers. In addition to this, it was aimed to examine whether the social values of the primary school teachers differ according to their gender and seniority, and the pre-service teachers according to their gender and grade levels. In this research, descriptive research model was used to determine the current situation. The population and sample of the research consist 343 primary school teachers working in primary schools affiliated to the Nevşehir Directorate of National Education and 253 pre-service teachers that are studying at Nevşehir Hacı Bektaş Veli University Faculty of Education. "Multidimensional Social Values Scale" was used to obtain the data of the research and the data were analyzed in computer environment. Independent samples t-test (independent sample $t$-test), Mann-Whitney $U$ test, One-way variance analysis (One-way ANOVA) and Kruskal-Wallis Test were used to analyze the data collected in line with the subproblems of the research. As a result of the research, the highest and lowest social value expressions of the social values of primary school teachers and pre-service teachers show similarities. In this context, "I attach great importance to the individuals in my family." and "I believe there is a creator who created us." statements at the highest level, "My religious beliefs have a great influence on the events I encounter in life." statements have been at the lowest level. When looking at whether the social values of primary school teachers and pre-service teachers differ, it is seen that the social value score averages of pre-service teachers are higher, but there is no significant difference.

Keywords: Primary School Teachers and Pre-service Teachers, Value, Social Values, Gender, Seniority, Grade Level

\section{Giriş}

Eğitim, "Bir toplumun ya da bireyin sahip olduğu kültürü, bilgiyi, inanc1, beceriyi, değerleri, sanatı ve benzerlikleri kendisinden sonra gelenlere aktarma sürecidir. Kısaca eğitim, kişinin davranış örüntülerini değiştirme sürecidir”(Tezcan, 2018). Eğitimin en önemli ve vazgeçilmez amaçlarından biri de toplumun değer yargılarını gelecek nesillere aktarmaktır (Akbaba Altun, 2003). Eğitimin bireyleri duyuşsal, bilişsel ve psikomotor yönden geliştirerek toplumun ilerlemesine olanak sağladığı söylenebilir. Türk milli eğitimin genel amaçlarına bakıldığında ise, bu amaçlar arasında Türk milletinin milli, insani, ahlaki ve kültürel değerlerini benimseyen, koruyan ve geliştiren; ailesini, milletini, vatanını seven; beden, zihin, ahlak, ruh ve duygu bakımlarından dengeli ve sağlıklı şekilde gelişmiş bir kişiliğe ve karaktere, hür ve bilimsel düşünme gücüne, geniş bir dünya görüşüne sahip; insan haklarına saygıll, kişilik ve teşebbüse değer veren, topluma karşı sorumluluk duyan; yapıcı, yaratıcı ve verimli kişiler olarak yetiştirmektir (MEB, 2005). Eğitimin, insanın ve toplumun her yönden gelişimini esas aldığı, temelinin de değerlere dayandırıldığı görülmektedir. Çünkü toplumun varlığının ve birliğinin devamı değerler ile mümkündür.

Değerler, toplumun hedeflediği arzu ettiği güzel tutum ve davranışlardır. Değerler; toplumun mevcudiyeti, birliği, işleyişi ve sürekliliği için toplumun neredeyse tamamı tarafından kabul edilmiş temel kaide ve kurallardır (Aktepe, 2014). Türk Dil Kurumuna göre değer; 'Bir ulusun sahip olduğu sosyal, kültürel, ekonomik ve bilimsel değerlerini kapsayan maddi ve manevi 
öğelerin bütünüdür' (TDK, 2011, s. 607). Değerler toplum ve birey tarafından kabul gören yargılardır ve kişinin sosyal ihtiyaçlarını karşıladığını düşünülen ölçütlerdir (MEB, 2005). Değerler, insan davranışlarına dayanır. Bir şeye verilen kıymet ve faydalı niteliktir. Kişinin nesne ile bağlantısındaki en önemli etkendir (Tezcan, 2018). Kısacası değerler, toplumun kültürünü oluşturan, toplumun birliğini, devamını ve düzenini sağlayan, toplumun duygu ve düşüncelerini ortaya koyan ve davranış tarzını belirleyen ölçütlerdir denebilir.

Toplum, yalnızca bir arada etkileşim içinde bulunmayan insanların oluşturduğu bir birliktelik değildir. Toplumu oluşturan insanların arasında bir bağ, etkileşim ve bir amaç vardır. Bu unsurların devamının sağlanması birtakım değerlerin toplumca benimsenmesi ile mümkündür (Yontar, 2019). Göz (2016)'e göre bu birlikteliği ve sürekliliği sağlayabilecek ortak değerler sevgi, hoşgörü, doğruluk, kardeşlik, yardımlaşma, saygı, dayanışma, eşitlik, hürriyet ve adalet olarak sıralanabilir. Bu birlikteliğin devamı değerlerin aktarılmasıyla mümkündür. Toplumun geneli tarafından kabul edilen en iyi, en doğru, en güzel değerler aktarlır. Bu değerler her toplumun kültürüne, inancına, ideolojisine göre değişiklik gösterebilir. İnsanlar sosyal bir yapı içinde yaşamakta ve bu yapı içinde büyümektedir. İnsanın toplum içinde yaşaması onun bireyselliğinden siyrılmasina sebep olmuştur (Düzgün,2007). Birey içinde doğduğu toplumun toplumsal değerlerini hazır olarak alıp zamanla benimser bu nedenle bireyin düşünceleri genellikle toplumun değerleriyle uyumludur (Altay,1971'den Akt. Ulusoy ve Dilmaç, 2016: 39). Toplumlar kendine özgü oluşan değerleri kendi toplumlarına ait yeni nesillerin tanımalarını, yaşamalarını ve yaşatmalarını istemiştir (Tezcan, 2018). Bu bağlamda değerlerin sosyal yaşam içindeki yeri ve önemi oldukça fazladır. Değerlerin toplumsal yaşamdaki yerini ve önemini vurgulamak için bazı araştırmacılar değerleri sınıflandırmışlardır.

Değerlerle ilgili yapılmış birçok sınıflama vardır. Ancak araştırmanın konusuyla ilgili olan "sosyal değer" sınıflandırmalarını burada ele almak doğru olacaktır. Değerlerin "sosyal değer" sınıflamasını belki de ilk yapan kişi Spranger'dir. Akbaş (2004), Spranger’ın 1928 yılında değerler sınıflandırmasını "bilimsel, ekonomik, estetik, sosyal, politik ve dini değerler" olarak altı grupta belirtmiştir. Yine Naylor and Diem (1987), Nelson'un 1974 yılında değerler sınıflandırmasını "Bireysel, grup ve sosyal değerler" olarak üçe ayırdığını ifade etmiştir. Güngör (1998) değerleri "estetik, teorik, iktisadi, siyasi, sosyal ve dinî değerler" olarak ele almıştır. Acat ve Aslan (2012) ise değerleri "muhafazakâr-geleneksel, ulusal-milli, öze dönük-kişisel, sosyal-toplumsal, bilimselyenilikçi” olarak ifade etmiştir. Son olarak Aktepe ve Gündüz (2018) değerleri "milli, dini, evrensel, insani, bireysel ve toplumsal/sosyal değerler" şeklinde belirtmiştir. Toplumsal/sosyal değerleri de misafirpervelik dayanışma, işbirliği ve çalışkanlık olarak ele almıştır.

Değerler insanlara özgüdür ve toplumsal hayatımızı oluşturur. Sosyal değerlerin varoluş sebebi ve kaynağı olan insan doğası, değerlerin yer aldığı toplumsal hayatın ve toplumsal değişim isteğinin de kaynağında yer alır (Yazıcı, 2014). Sosyal değerler, bireysel ve sosyal hayatımızın temelini oluşturan, kişi ve topluma sorumluluklar yükleyen, onların hareket ve davranışlarının temel normunu belirleyen, insana ve topluma bir amaç ve hedef sunan değerlerdir. Bu değer toplumun maddi ve manevi değerlerini şekillendirir ve oldukça önemlidir. Sosyal değerlerin temelini değer felsefesi ve değer sosyolojisi oluştursa da sadece bununla sınırlandırmak doğru olmayacaktır. Sosyal değerler insani değerler olduğu için hukukta, adalette, anlaşmalarda, estetikte kısaca hayatımızın her yerinde her anında vardır ve hayatımıza anlam katar (Sarı; 2013). 
Bu bağlamda sosyal değerlerin öğretiminde değerler eğitiminden yararlanılabilir. Nitekim sosyal değerler, insan ve topluma ait davranış tarzlarını ortaya koymaktadır. Bu anlamda sosyal değerler; bireyin kendine özgü davranışlarını sosyal yapı içerisinde oluşturması, topluma uyum sağlaması ve sosyalleşmesi, toplum hayatındaki sosyal ilişkileri, toplumsal yaşanan değişimlere uyum sağlaması gibi birçok etken düşünüldüğünde konunun değerler eğitimiyle ilişkili olduğu görülmektedir.

Değer eğitimi süreç içerisinde değişime uğramıştır. 1950’li yıllarda topluma uyum sağlama önemsenirken, 1960'lı yıllarda bireysellik, topluma bağlılık ve toplumda demokrasinin gelişmesi ön plandayken, 1980'li yıllarda teknik ve araçsal düşünme ön plana çıkmıştır ve değer eğitimi önemini kaybetmiştir. 2000' li yıllarda da değerler eğitimi yerine bireysellik ön plandadır fakat günümüzde çocukların doğruyla yanlışı karıştırması, bencil ve umursamaz olmaları, dürüstlük yerine yalan ve şiddeti kullanmaları, huzurun sadece maddi olarak elde edilebileceğini düşünmeleri gibi sebeplerden dolayı değerler eğitimi önemsenmiş ve zorunlu hale gelmiştir (Tezcan, 2018). Bu bağlamda günümüzde art arda yaşanan şiddet olayları, artan yolsuzluklar, kapkaç ve hırsızlık olayları vb. toplumlarda temel değerlerin giderek önemsenmediği ve kaybolmakta olduğunun göstergeleridir. Bundan dolayı temel değerleri hayatımızın merkezine alan ve temel değerleri önemseyen ve yaşatan bireylere daha çok ihtiyacımız bulunacaktır. Bu ise ancak değerler eğitimi ile mümkün olabilir (Budumlu Akkiprik, 2007).

Değerler Eğitimi, bilişsel bilgiye ek olarak öğrencinin kişiliğini iyileştirmesi, geliştirmesi ve topluma yönelik sorumluluklarının öğretilmesidir (Ulusoy ve Arslan, 2014). UNESCO (2002) tarafından değerler eğitimi tanımı ise "Çocukların ve gençlerin pozitif değerleri keşfedip geliştirmeleri ve kendi potansiyellerine göre ilerlemeleri için yürütülen eğitimsel gayretler” olarak belirtilmiştir. “Toplumsal hayatı oluşturan, insanları birbirine bağlayan, gelişmeyi, mutluluğu ve huzuru sağlayan, risk ve tehditlerden koruyan ahlaki, insani, sosyal, manevi değerlerimizin tüm bireylere kazandırılmasında en önemli etken eğitimdir. Bu kazanımlarımızın öğrencilerimize aktarılması da değerler eğitimini oluşturmaktadır.” (MEB, 2010).

Eğitim alanında da değerlerin önemli bir yeri vardır. Okul, değerler üzerine yapılandırılmış bir yaşama ve öğrenme alanıdır (Turan ve Aktan, 2008). Değerlerin aktarımında en önemli ve en büyük görev okullara düşmektedir. Çünkü değerler eğitiminin öğretiminde okullar çok önemlidir. Okullarda değer eğitimine yer verilmesinin amacı toplumun ihtiyacını karşılamaktır (Ulusoy ve Dilmaç, 2016). Değerler eğitimi gelişigüzel verilmemeli belirli bir plan ve program dâhilinde yürütülmelidir (Dilmaç ve Ekşi, 2007). Bu planlar daha çok okul çatısı altında öğretim programlarında yer alan hedef ve kazanımlarla gerçekleştirilmektedir (Katılmış ve Balcı, 2017).

Milli Eğitim Bakanlığı (MEB) 2020'de yayınlanan değerler eğitimi yönergesine göre değerler eğitiminin büyük bir titizlikle yürütülmesi gerektiği ve ulusal ve evrensel değerlerimizin değerler eğitimi ile ilişkilendirilmesi gerektiği yer almaktadır. Bu değerlerin aktarımında okul sürecinin en mühim etkeni olan öğretmenlerin önemli sorumlulukları bulunmaktadır. Öğretmenlerin sahip olduğu değerleri öğrencilere kazandırmada, öğretmenlerin değerleri bilmesi ve günlük yaşamda bunları davranışlarına yansıtması bu süreçte öğrenciler için önem arz etmektedir (Tonga, 2017). Değer öğretimini yaparken öğretimin temeli olan, öğretim programlarını uygulayan ve öğrenciler üzerindeki etkisinin en fazla ve derin olduğu düşünülen öğretmenleri büyük sorumluluklar beklemektedir (Şen, 2007: 15). Öğretmenlerin, öğrenciler için model teşkil 
ettiğinin kaçınılmaz bir gerçek olduğu düşünüldüğünde, öğretmenlerin sergiledikleri davranışların ve benimsedikleri ilkelerin öğrencileri etkileyeceği düşünülerek üzerinde durulması gerekmektedir (Gökdere ve Çepni, 2011). Öğretmen, her alanda tavır ve davranışlarına dikkat etmelidir. Okul içinde ve okul dışında öğrencisine örnek bir model olmalıdır. Öğretmen, okulda öğrencilerine kendi bilgi ve becerilerini aktarırken kendi benimsediği değer yargılarını da aktarır. Bu süreçte öğretmenlerin benimsedikleri değerler önem arz etmektedir (Aktepe ve Yel, 2009). Aktepe ve Tahiroğlu (2016)'na göre öğretmenlerin etkili olacak bir değerler eğitiminde uygun olan yaklaşım, strateji, yöntem ve teknikleri uygulaması ve bu uygulamada çocuğun gerçek yaşamıyla ilişkili olacak etkinliklere yer vermesi gerekmektedir. Öğrenciyi birçok yönden geliştirecek öğrenme-öğretme süreci ile desteklemesi, uygun bir ölçme ve değerlendirme yöntemiyle sonuçlandırması gerektiğinin üzerinde durmaktadırlar. Özmen, Er ve Gürgil (2012) ise, geleceğin öğretmenleri olarak öğretmen adaylarının nasıl bir kültürden geçtiklerinin ve değerleri nasıl oluşturduklarının bilinmesinin önemine vurgu yapmaktadır. Nitekim öğretmenlerin benimsediği değerler öğrenci davranışlarını etkilemektedir.

\section{Araştırmanın Önemi}

Değerler eğitiminde kilit bir rol üstlenen sınıf öğretmenlerinin gerek hizmet öncesinde gerekse hizmet içinde sosyal değerler açısından iyi yetiştirilmesi gerekmektedir. Bu bağlamda sınıf öğretmenlerinin; insani değerlerle donatılmış, toplumla uyumunu tamamlamış ve bilişsel, duyuşsal ve sosyal olarak gelişimini tamamlamış olmaları arzu edilmektedir. Bu bağlamda ilkokulda görev yapan sınıf öğretmenlerinin değerleri son derece önemli görülmektedir. $\mathrm{Bu}$ araştırmada sınıf öğretmenlerinin ve adaylarının sosyal değerleri incelenmektedir. Sınıf öğretmenlerinin ve adaylarının sosyal değerlerinde görülen eksikliklerin tespit edilmesi ve gerekli önlemlerin alınması araştırmayı önemli kılmaktadır.

\section{Araştırmanın Amacı}

Araştırmada sınıf öğretmenleri ve sınıf öğretmeni adaylarının sosyal değerlerinin belirlenmesi ve belirlenen birkaç değişken açısından incelenmesi ve karşılaştırılması amaçlanmaktadır. Bu amaç temel alınarak araştırmada şu sorulara yanıt aranmıştır:

1. Sınıf öğretmenlerinin sahip oldukları sosyal değerleri nelerdir?

2. Sınıf öğretmenlerinin sahip oldukları sosyal değerleri cinsiyet açısından farklılık göstermekte midir?

3. Sınıf öğretmenlerinin sahip oldukları sosyal değerleri kıdemlere göre farklılık göstermekte midir?

4. Sınıf öğretmeni adaylarının sahip oldukları sosyal değerleri nelerdir?

5. Sınıf öğretmeni adaylarının sahip oldukları sosyal değerleri cinsiyet açısından farklılık göstermekte midir?

6. Sınıf öğretmeni adaylarının sahip oldukları sosyal değerleri sınıf seviyelerine göre farklılık göstermekte midir?

7. Sınıf öğretmenleri ve sınıf öğretmeni adaylarının sahip oldukları sosyal değerleri farklılık göstermekte midir? 


\section{Yöntem}

\section{Araştırma Modeli}

Araştırmada, sınıf öğretmenlerinin ve sınıf öğretmeni adaylarının sosyal değerlerini olduğu gibi yani var olan durumu olduğu şekliyle ortaya koyduğundan betimsel araştırma modeli kullanılmıştır. Betimsel araştırmalar verilen bir durumu dikkatli bir şekilde ve tam olarak tanımlar (Büyüköztürk, Çakmak, Akgün, Karadeniz ve Demirel, 2016). Araştırmada sınıf öğretmenlerinin ve sınıf öğretmeni adaylarının sosyal değerleri belirlenmiş; cinsiyet, sınıf seviyesi ve kıdem değişkenleri açısından incelenmiş ve karşılaştırması yapılmıştır.

\section{Evren ve Örneklem}

Nevşehir Milli Eğitim Müdürlügüne bağlı ilkokullarda görev yapan 343 sınıf öğretmeni ve Nevşehir Hacı Bektaş Üniversitesi Eğitim Fakültesinde okuyan 253 sınıf öğretmeni adayı araştırmanın örneklemini oluşturmaktadır. Araştırmada amaçsal örnekleme yöntemlerinden tipik durum örnekleme yöntemi kullanılmıştır. Büyüköztürk vd. (2016) göre tipik durum örnekleme yöntemi, evrende yer alan durumlar içerisinden tipik olan, sıra dişı olmayan ve araştırma problemine uygun bir örneklem üzerinden bilgi toplamayı amaçlayan yöntemdir. Araştırmaya katılan öğretmen ve öğretmen adaylarının kişisel bilgilerine Tablo 1 ve Tablo 2'de yer verilmiştir.

Tablo 1. Sını Öğretmenlerinin Kişisel Bilgileri

\begin{tabular}{llcc}
\hline Kişisel Bilgiler & & $\mathbf{n}$ & $\%$ \\
\hline Cinsiyet & Kadın & 231 & 67.3 \\
& Erkek & 112 & 32.7 \\
\hline Kıdem & $0-12$ ay & 34 & 9.9 \\
$1-5$ yll & 27 & 7.9 \\
& $6-10$ yll & 46 & 13.4 \\
$11-15$ yll & 51 & 14.9 \\
& $16-20$ yıl & 46 & 13.4 \\
& 21 ve üzeri & 139 & 40.5 \\
\hline
\end{tabular}

Araştırmaya katılan çalışma grubunun kişisel bilgileri Tablo 1'e bakıldığında \%67,3'ünü kadın, \%32,7'sini erkeğin oluşturduğu görülmektedir. Öğretmenleri kıdemleri incelendiğinde \%40,5'ini 21 ve üzeri, \%14,9'unu 11-15 yıl arası, \%13,4' ünü 6-10 yıl ve 16-20 yıl, \%9,9'unu 0-12 ay ve \%7,9'unu 1-5 yıl kıdeme sahip olan sınıf öğretmenleri oluşturmaktadır.

Tablo 2. Sınıf Öğretmeni Adaylarının Kişisel Bilgileri

\begin{tabular}{lccc}
\hline Kişisel Bilgiler & & $\mathbf{n}$ & \% \\
\hline Cinsiyet & Kadın & 208 & 82.2 \\
& Erkek & 45 & 17.8 \\
\hline Sinıf seviyesi & 1. Sinıf & 39 & 15.4 \\
& 2. Sinıf & 103 & 40.7 \\
& 3. Sinıf & 64 & 25.3 \\
& 4. Sinıf & 47 & 18.6 \\
\hline
\end{tabular}


Araştırmaya katılan çalışma grubunun kişisel bilgileri Tablo 2'ye bakıldığında \%82.2'sini kadın, \%17,8’ini erkeğin oluşturduğu görülmektedir. Öğretmen adaylarının sınıf seviyeleri incelendiğinde \%40.7'sini 2.sınıf, \%25.3'ünü 3.sınıf, \%18.6'sını 4.sinıf ve \%15.4'ünü 1.sınıf oluşturmaktadır.

\section{Veri Toplama Aracı}

Çalışmada öğretmenlerin ve öğretmen adaylarının sosyal değerlerini belirlemek amacıyla "Çok Boyutlu Sosyal Değerler Ölçeği” kullanılmıştır. Ölçek, Bolat (2013) tarafından geliştirilmiştir. Bu ölçeğin Cronbach Alpha ( $\alpha$ ) güvenilirlik katsayısı değeri .82 olarak hesaplanmıştır. Ölçekte öğretmenlerin ve öğretmen adaylarının sosyal değerlerini ölçmek amacı ile "hiç katılmıyorum", "katılmıyorum", "kısmen katılıyorum”, "katılıyorum" ve "tamamen katılıyorum” biçiminde beşli likert tipi dereceleme maddelerinden yararlanılmıştır.

\section{Verilerin Toplanması ve Analiz Edilmesi}

Veriler bilgisayar programı aracılığı ile analiz edilmiştir. Sınıf öğretmenlerinden toplanan veriler normal dağılım göstermediği için problemler doğrultusunda Mann-Whitney U Testi ve KruskalWallis Testi uygulanıp analiz edilmiştir. Sınıf öğretmeni adaylarından toplanan veriler normal dağılım gösterdiği için problemler doğrultusunda Bağımsız Örneklemler t-testi (İndependent Sample t-testi) ve Tek Yönlü Varyans Analizi (One - way ANOVA) uygulanıp ve analiz edilmiştir.

Ölçekte her soruya verilecek cevap puanları 1.00 ile 5.00 arasında değişmektedir. Sınıflama ölçeği oluşturulurken; 'aralık genişliği(a) = Dizi genişliği/yapılacak grup sayısı' formulü uygulanmıştır. Buna göre oluşturulan ölçekte; nitelik grupları, nitelik gruplarının sınırları ve verilen puanlar aşağıda Tablo 3'de gösterilmiştir.

Tablo 3. Nitelik Gruplarının Sınırları ve Verilen Puan Ölçeği

\begin{tabular}{lll}
\hline Verilen Puan & Nitelik Grupları & Sınırı \\
\hline 5 & Tamamen Katıllyorum & $4.20-5.00$ \\
4 & Katıllyorum & $3.40-4.19$ \\
3 & Kısmen Katıllyorum & $2.60-3.39$ \\
2 & Katılmıyorum & $1.80-2.59$ \\
1 & Hiç Katılmıyorum & $1.00-1.79$ \\
\hline
\end{tabular}

Tablo 3 incelendiğinde, araştırmaya katılan çalışma grubunun verdiği puanlar ve grupların sinırları verilmektedir. 4.20-5.00 puan aralığı “Tamamen katılıorum"a, 3.40-4.19 “Katılıorum”a, 2.60-2.59 “Kısmen katılıyorum”a 1.80-2.59 “Katılmıyorum”a ve 1.00-1.79 “Hiç katılmıorum"a tekabül etmektedir.

\section{Bulgular ve Yorum}

\section{Sınıf Öğretmenlerinin Sahip Oldukları Sosyal Değerleri Nelerdir?}

Araştırmada ilk olarak, sınıf öğretmenlerinin sosyal değerlerinin standart sapması ve aritmetik ortalaması belirlenip Tablo 4' de verilmiştir. 


\section{Tablo 4. Sınıf Ö̆̆retmenlerinin Sahip Oldukları Sosyal Değerleri}

\begin{tabular}{|c|c|c|c|}
\hline & Sosyal Değerlere Yönelik Maddeler & $\overline{\boldsymbol{X}}$ & $\mathbf{S}$ \\
\hline 1 & Zor durumdaki insanların sorunları çözmek için onlarla birlikte hareket ederim. & 4.37 & .74 \\
\hline 2 & Düşünce sistemime uymayan insanları karşı taraf olarak algılarım. & 3.77 & 1.1 \\
\hline 3 & Rekabeti başarıya götüren bir araç olarak görürüm. & 2.68 & 1.0 \\
\hline 4 & İnsanların bana güvenmesi önemlidir. & 4.63 & .66 \\
\hline 5 & Ailemdeki bireylere büyük önem veririm. & 4.77 & .53 \\
\hline 6 & Birlikte çalışmayı yalnız çalışmaya tercih ederim. & 3.40 & 1.1 \\
\hline 7 & Parayı insanlar arasında bir güç kaynağı olarak görürüm. & 3.20 & 1.2 \\
\hline 8 & Devlet yönetiminde din etkili olabilir. & 2.63 & 1.2 \\
\hline 9 & Aile yönetiminde kadın etkin rol oynamalıdır. & 4.11 & .92 \\
\hline 10 & Karşıt fikirdeki insanların düşüncelerinin de değerli olabileceğini bilirim. & 4.29 & .76 \\
\hline 11 & Çalışkan insanları hep takdirle karşılarım. & 4.55 & .68 \\
\hline 12 & Başkalarına iyilikte bulunmaktan hoşlanırım. & 4.65 & .63 \\
\hline 13 & Kul hakkına saygılı olmak toplumda eşit paylaşıma yardımcı olmaktadır. & 4.57 & .75 \\
\hline 14 & Yaşadığım ortamlarda genel hijyen kurallarına uyarım. & 4.65 & .56 \\
\hline 15 & Her ne pahasına olursan olsun dürüst davranırım. & 4.40 & .75 \\
\hline 16 & Bir aileye sahip olmanın gerekliliğini kabul ederim. & 4.64 & .63 \\
\hline 17 & Mesleki kariyerimde paradan çok etik değerlere önem veririm. & 4.51 & .73 \\
\hline 18 & Alışverişte satıcı indirim yapıyorsa fatura almam. & 3.78 & 1.1 \\
\hline 19 & Hayallerimde yeni şeyler tasarlarım. & 3.79 & .93 \\
\hline 20 & Başka bir ülkeden iyi bir iş teklifi alırsam o ülke vatandaşlığına geçebilirim. & 3.75 & 1.3 \\
\hline 21 & Başkalarıyla yarışma ortamı içinde çalışabilirim. & 2.99 & 1.1 \\
\hline 22 & Dini inanışlarım hayatta karşılaştığım olaylar üzerinde büyük etkiye sahiptir. & 2.58 & 1.1 \\
\hline 23 & Bilimsel olarak kanıtlanmış bilgiye önem veririm. & 4.53 & .61 \\
\hline 24 & Kadının çalışma hayatına katılmasının aile yapısına zarar verdiğine inanırım. & 4.03 & 1.2 \\
\hline 25 & Çevremdeki insanların davranışlarının nedenlerini anlamaya çalışırım. & 4.13 & .73 \\
\hline 26 & Günlük hayatta israfa neden olacak davranışlardan uzak durmaya çalışırım. & 4.39 & .67 \\
\hline 27 & Çalışkan, işe yarar biri olmak benim için önemlidir. & 4.63 & .60 \\
\hline 28 & Ordunun ve askerlik hizmetinin kutsallığına inanırım. & 4.28 & .94 \\
\hline 29 & Benim kültür yapıma uygun bir eşle mutlu olabileceğime inanırım. & 4.33 & .82 \\
\hline 30 & Bilinçli bir seçmen olarak vatandaşlık görevimi yerine getiririm. & 4.68 & .55 \\
\hline 31 & Bizi yaratan bir yaratıcı olduğuna inanırım. & 4.74 & .72 \\
\hline 32 & Herkesçe bilinen bilgileri sorgulama ihtiyacı duyarım. & 3.98 & .85 \\
\hline 34 & Bana güven vermeyen insanlarla ilişki kurmaktan uzak durmaya çalışırım. & 4.36 & .74 \\
\hline 35 & Milli değerlerden kesinlikle ödün vermeyen bir düşünce sistemi içinde yaşarım. & 4.08 & .94 \\
\hline 36 & İbadetin, insanların hoşgörülü davranış geliştirmelerini sağladığına inanırım. & 3.96 & 1.1 \\
\hline
\end{tabular}


Tablo 4. incelendiğinde sınıf öğretmenlerinin sosyal değer olarak en yüksek puan ortalamaları şöyledir: “Ailemdeki bireylere büyük önem veririm.” (4.77), maddesinde sınıf öğretmenleri (\%81.3) oranında "tamamen katılıyorum"u işaretlemişlerdir. "Bizi yaratan bir yaratıcı olduğuna inanırım.” (4.74), sınıf öğretmenleri bu maddede (\%85.1) oranında "tamamen katılıorum”u seçmişlerdir. "Bilinçli bir seçmen olarak vatandaşlık görevimi yerine getiririm." (4.68), maddesinde (\%71.4) oranında "tamamen katılıyorum"u işaretlemişlerdir. "Yaptığım işlerde görev bilinci ve sorumluluğuyla hareket ederim." (4.67), maddesinde (\%70.6) oranında "tamamen katılıyorum"u işaretlemişlerdir. "Başkalarına iyilikte bulunmaktan hoşlanırım." (4.65), maddesinde (\%72.3) oranında "tamamen katılıyorum”u işaretlemişlerdir. "Yaşadığım ortamlarda genel hijyen kurallarına uyarım.” (4.65), maddesinde sınıf öğretmenleri (\%69.4) oranında "tamamen katılıyorum"u işaretlemişleridir. "Bir aileye sahip olmanın gerekliliğini kabul ederim." (4.64), maddesinde (\%71.1) oranında "tamamen katılıyorum"u seçmişlerdir. "Çalışkan, işe yarar biri olmak benim için önemlidir." (4.63), maddesinde ise (\%68.2) oranında "tamamen katılıyorum" seçeneğine işaretleme yapmışlardır. "İnsanların bana güvenmesi önemlidir." (4.63), maddesinde (\%70.8) oranında "tamamen katılıyorum"u işaretlemişlerdir. "Mesleki kariyerimde paradan çok etik değerlere önem veririm." (4.51), maddesinde (\%62.4) oranında sınıf öğretmenleri "tamamen katılıyorum” seçeneğini işaretlemişlerdir.

Sınıf öğretmenlerinin sosyal değer olarak kısmen katılıyorum düzeyinde puan ortalamaları şöyledir: "Devlet yönetiminde din etkili olabilir." (2.63), maddesinde sinıf öğretmenleri (\%25.9) oranında "kısmen katılıyorum"u işaretlemişlerdir. "Rekabeti başarıya götüren bir araç olarak görürüm." (2.68), maddesinde (\%40.8) oranında "kısmen katılıyorum"u işaretlemişlerdir. "Başkalarıyla yarışma ortamı içinde çalışabilirim." (2.99), maddesinde (\%29.7) oranında "kısmen katılıyorum"u işaretlemişlerdir. "Parayı insanlar arasında bir güç kaynağı olarak görürüm.” (3.20), maddesinde ise $(\% 32,1)$ oranında "kısmen katılıyorum" seçeneğini işaretlemişlerdir.

Sınıf öğretmenlerinin sosyal değer olarak en düşük puan ortalamaları ise şöyledir: "İspatı mümkün olmayan bilgi ve düşüncelerin güvenilir olmadığına inanırım.” (2.57), maddesinde (\%39.7) oranında "katılmıyorum"u işaretlemişlerdir. "Dini inanışlarım hayatta karşılaştı̆̆ım olaylar üzerinde büyük etkiye sahiptir." (2.58), maddesinde (\%31.5) oranında "katılmıyorum" seçeneğini işaretlemişlerdir.

\section{Sınıf Öğretmenlerinin Sahip Oldukları Sosyal Değerleri Cinsiyet Açısından Farklılık Göstermekte midir?}

Sınıf öğretmenlerinin sosyal değerlerine yönelik cinsiyet açısından farklılığı analiz edilerek sonuçlar tablo 5'de verilmiştir.

Tablo 5. Sınıf Öğretmenlerinin Sahip Oldukları Sosyal Değerlerinin Cinsiyete Göre Farklılığına Yönelik Mann-Whitney U Testi Sonuçları

\begin{tabular}{llllll}
\hline Grup & $\mathbf{n}$ & Sira Ortalaması & Sira Toplamı & U & p \\
\hline Kadın & 231 & 176.55 & 40783,50 & 11884,500 &, 222 \\
Erkek & 112 & 162.61 & 18212,50 & & \\
\hline
\end{tabular}

${ }^{\star} \mathrm{p}>.05$ 
Sınıf öğretmenlerinin sosyal değerlerinin cinsiyetlerine göre farklılaşıp farklılaşmadığı uygulanan Mann-Whitney U Testi ile test edilmiş, aralarında anlamlı bir farklılık bulunmamıştır $(\mathrm{U}=11884,500 ; \mathrm{z}=-1,222)$. Elde edilen bulgulara göre kadın sınıf öğretmenlerinin sahip olduğu sosyal değerler ile erkek sınıf öğretmenlerin sahip olduğu sosyal değerlerin benzerlik gösterdiği söylenebilir.

\section{Sınıf Öğretmenlerinin Sahip Oldukları Sosyal Değerleri Kıdemlere Göre Farklılık Göstermekte midir?}

Tablo 6. Sınıf Öğretmenlerin Sahip Oldukları Sosyal Değerlerinin Kıdemlerine Göre Farklılı̆̆ına Yönelik Kruskal-Wallis Testi Sonucu

\begin{tabular}{lccccc}
\hline \multicolumn{1}{c}{ Gruplar } & n & Sira Ortalaması & sd & $\mathbf{X}^{\mathbf{2}}$ & $\mathbf{p}$ \\
\hline $0-12$ ay & 34 & 171.37 & & & \\
$1-5$ yll & 27 & 148.76 & & 5.142 & .399 \\
$6-10$ yll & 46 & 187.74 & 5 & & \\
$11-15$ yll & 51 & 174.46 & & & \\
$16-20$ yll & 46 & 151.12 & & & \\
21 ve üzeri & 139 & 177.47 & & & \\
\hline
\end{tabular}

${ }^{*} \mathrm{p}>.05$

Sınıf öğretmenlerinin sosyal değerlerinin kıdemlerine göre farklılık gösterip göstermediği yapılan Kruskal - Wallis Testi ile analiz edilmiştir. Test sonucu sınıf öğretmenlerin sosyal değerlerinin kıdemlerine göre anlamlı düzeyde farklılık göstermediği görülmektedir $\left(\mathrm{x}_{(5)}^{2}=5.142, \mathrm{p}>.05\right)$. Nitekim kıdem olarak sınıf öğretmenlerinin benzer sosyal değerleri sahip olduğu ve kıdem açısından bir değişiklik göstermedikleri söylenebilir.

\section{Sınıf Öğretmeni Adaylarının Sahip Oldukları Sosyal Değerleri Nelerdir?}

\section{Tablo 7. Sınıf Ö ğretmeni Adaylarının Sahip Oldukları Sosyal Değerler}

\begin{tabular}{llcc}
\hline & Sosyal Değerlere Yönelik Maddeler & $\overline{\boldsymbol{X}}$ & $\mathbf{S}$ \\
\hline $\mathbf{1}$ & Zor durumdaki insanların sorunları çözmek için onlarla birlikte hareket edı & 4.23 & .67 \\
\hline $\mathbf{2}$ & Düşünce sistemime uymayan insanları karşı taraf olarak algılarım. & 3,73 & .99 \\
\hline $\mathbf{3}$ & Rekabeti başarıya götüren bir araç olarak görürüm. & 2.85 & 1.0 \\
\hline $\mathbf{4}$ & İnsanların bana güvenmesi önemlidir. & 4.51 & .71 \\
\hline $\mathbf{5}$ & Ailemdeki bireylere büyük önem veririm. & 4.77 & .53 \\
\hline $\mathbf{6}$ & Birlikte çalı̧̧mayı yalnız çalı̧̧maya tercih ederim. & 2.92 & 1.0 \\
\hline $\mathbf{7}$ & Parayı insanlar arasında bir güç kaynağı olarak görürüm. & 3.25 & 1.2 \\
\hline $\mathbf{8}$ & Devlet yönetiminde din etkili olabilir. & 2.66 & 1.1 \\
\hline $\mathbf{9}$ & Aile yönetiminde kadın etkin rol oynamalıdır. & 4.13 & .92 \\
\hline $\mathbf{1 0}$ & Karşıt fikirdeki insanların düşüncelerinin de değerli olabileceğini bilirim. & 4.41 & .70 \\
\hline $\mathbf{1 1}$ & Çalışkan insanları hep takdirle karşlarım. & 4.34 & .70
\end{tabular}




\begin{tabular}{|c|c|c|c|}
\hline 12 & Başkalarına iyilikte bulunmaktan hoşlanırım. & 4.65 & .54 \\
\hline 13 & Kul hakkına saygılı olmak toplumda eşit paylaşıma yardımcı olmaktadır. & 4.51 & .66 \\
\hline 14 & Yaşadığım ortamlarda genel hijyen kurallarına uyarım. & 4.50 & .64 \\
\hline 15 & Her ne pahasına olursan olsun dürüst davranırım. & 3.96 & .83 \\
\hline 16 & Bir aileye sahip olmanın gerekliliğini kabul ederim. & 4.53 & .68 \\
\hline 17 & Mesleki kariyerimde paradan çok etik değerlere önem veririm. & 4.23 & .76 \\
\hline 18 & Alışverişte satıcı indirim yapıyorsa fatura almam. & 3.88 & 1.0 \\
\hline 19 & Hayallerimde yeni şeyler tasarlarım. & 4.07 & .86 \\
\hline 20 & Başka bir ülkeden iyi bir iş teklifi alırsam o ülke vatandaşlığına geçebilirim. & 3.46 & 1.2 \\
\hline 21 & Başkalarıyla yarışma ortamı içinde çalışabilirim. & 2.85 & 1.0 \\
\hline 22 & Dini inanışlarım hayatta karşılaştığım olaylar üzerinde büyük etkiye sahipti & 2.56 & 1.0 \\
\hline 23 & Bilimsel olarak kanıtlanmış bilgiye önem veririm. & 4.25 & .66 \\
\hline 24 & Kadının çalışma hayatına katılmasının aile yapısına zarar verdiğine inanırın & 4.54 & .86 \\
\hline 25 & Çevremdeki insanların davranışlarının nedenlerini anlamaya çalışırım. & 4.17 & .74 \\
\hline 26 & Günlük hayatta israfa neden olacak davranışlardan uzak durmaya çalışırım. & 4.15 & .74 \\
\hline 27 & Çalışkan, işe yarar biri olmak benim için önemlidir. & 4.49 & .64 \\
\hline 28 & Ordunun ve askerlik hizmetinin kutsallığına inanırım. & 4.37 & .80 \\
\hline 29 & Benim kültür yapıma uygun bir eşle mutlu olabileceğime inanırım. & 4.17 & .85 \\
\hline 30 & Bilinçli bir seçmen olarak vatandaşlık görevimi yerine getiririm. & 4.54 & .63 \\
\hline 31 & Bizi yaratan bir yaratıcı olduğuna inanırım. & 4.77 & .57 \\
\hline 32 & Herkesçe bilinen bilgileri sorgulama ihtiyacı duyarım. & 3.64 & .96 \\
\hline 33 & Sosyal yardımlaşmanın toplumun sorunlarını çözmekte etkili olacağına ina: & 4.37 & .66 \\
\hline 34 & Bana güven vermeyen insanlarla ilişki kurmaktan uzak durmaya çalışırım. & 4.24 & .89 \\
\hline 35 & Milli değerlerden kesinlikle ödün vermeyen bir düşünce sistemi içinde yaşa & 3.74 & .03 \\
\hline 36 & İbadetin, insanların hoşgörülü davranış geliştirmelerini sağladığına inanırır & 4.08 & .99 \\
\hline 37 & Yaptığım işlerde görev bilinci ve sorumluluğuyla hareket ederim. & 4.43 & .68 \\
\hline 38 & Laiklik, din ve vicdan özgürlüğünün korunması demektir. & 4.07 & .91 \\
\hline 39 & Bir aile kurduğumda eşimle uzun bir beraberlik sürdürebileceğimi düşünür & 4.36 & .72 \\
\hline 40 & Yapmak istediğim işin farklı bir yolunu ararım. & 3.96 & .73 \\
\hline 41 & Ortaya koyduğum davranışımın başkaları için doğuracağı sonuçlara dikkat & 4.11 & .74 \\
\hline \multirow[t]{2}{*}{42} & İspatı mümkün olmayan bilgi ve düşüncelerin güvenilir olmadığına inanırı & 2.63 & .90 \\
\hline & Genel Ortalama & 4.00 & 0,81 \\
\hline
\end{tabular}

Tablo 7. incelendiğinde sınıf öğretmeni adaylarının sosyal değer olarak en yüksek puan ortalamaları şöyledir: "Bizi yaratan bir yaratıı olduğuna inanırım." (4.77), sınıf öğretmeni adayları bu maddede (\%82.2) "tamamen katıllyorum"u işaretlemişlerdir. "Ailemdeki bireylere büyük önem veririm." (4.77), sinıf öğretmeni adayları bu maddede (\%70.8) "tamamen katılıyorum"u işaretlemişlerdir. "Başkalarına iyilikte bulunmaktan hoşlanırım." (4.65), maddesinde (\%68.4) oranında "tamamen katılıyorum" seçeneğini işaretlemişlerdir. 
Sınıf öğretmeni adaylarının sosyal değer olarak kısmen katılıyorum düzeyinde puan ortalamaları şöyledir: "Devlet yönetiminde din etkili olabilir." (2.66), maddesinde sınıf öğretmeni adayları (\%33.2) oranında "kısmen katılıyorum"u işaretlemişlerdir. "İspatı mümkün olmayan bilgi ve düşüncelerin güvenilir olmadığına inanırım.” (2.63), maddesinde (\%41.9) oranında "kısmen katılıyorum"u işaretlemişlerdir. "Rekabeti başarıya götüren bir araç olarak görürüm." (2.85), maddesinde (\%42.7) oranında "kısmen katılıyorum"u işaretlemişlerdir. "Başkalarıyla yarışma ortamı içinde çalışabilirim." (2.85), maddesinde (\%33.2) oranında "kısmen katılıyorum"u işaretlemişlerdir. "Birlikte çalışmayı yalnız çalışmaya tercih ederim.” (2.92), maddesinde (\%37.9) oranında "kısmen katılıyorum"u işaretlemişlerdir. "Parayı insanlar arasında bir güç kaynağı olarak görürüm." (3.25), maddesinde ise (\%32.4) oranında "kısmen katılıyorum" seçeneğini işaretlemişlerdir.

Sınıf öğretmeni adaylarının sosyal değer olarak en düşük puan ortalaması ise "Dini inanışlarım hayatta karşılaştığım olaylar üzerinde büyük etkiye sahiptir.” (2.56), maddesinde (\%33.2) oranında "katılmıyorum" seçeneğini işaretlemişlerdir.

\section{Sınıf Öğretmeni Adaylarının Sahip Oldukları Sosyal Değerleri Cinsiyet Açısından Farklılık Göstermekte midir?}

Tablo 8. Sınıf Öğretmeni Adaylarının Sahip Oldukları Sosyal Değerleri Cinsiyete Göre Farklılı̆̆ına Yönelik Bağımsız Örneklemler t-testi Sonuçları

\begin{tabular}{lcccccc}
\hline Grup & $\mathbf{n}$ & $\boldsymbol{X}$ & $\mathbf{s}$ & sd & t & P \\
\hline Kadın & 208 & 165.72 & 11.422 & 251 & 2.410 & .017 \\
Erkek & 45 & 161.15 & 12.043 & & & \\
\hline${ }^{*}$ p $<.05$ & & & & & &
\end{tabular}

Sınıf öğretmeni adaylarının sosyal değerlerinin cinsiyetlerine göre farklılık gösterip göstermediği yapılan Bağımsız Örneklemler t-testi sonucunda analiz edilmiştir. Bu analiz sonucunda sınıf öğretmeni adaylarının sosyal değerlerinin cinsiyetlere göre kadınlar lehine anlamlı derecede farklılık gösterdiği bulgusuna ulaşılmıştır $\left(\mathrm{t}_{(251)}=2.410, \mathrm{p}<.05\right)$. Sosyal değer ortalamalarına bakıldığında, kadın sınıf öğretmeni adaylarının puan ortalaması $(\bar{X}=165.72)$, erkeklerin puan ortalamasından $(\bar{X}=161.15)$ daha yüksek olduğu görülmektedir. Bu durumda kadın sınıf öğretmeni adaylarının sosyal değerleri, erkek sınıf öğretmeni adaylarına göre anlamlı oranda daha iyi durumdadır denilebilir.

Sınıf Öğretmeni Adaylarının Sahip Oldukları Sosyal Değerleri Sınıf Seviyelerine Göre Farklılık Göstermekte midir? 
Tablo 9. Sınıf Öğretmeni Adaylarının Sahip Oldukları Sosyal Değerleri Sınıf Seviyelerine Göre Farklılı̆̆ına Yönelik Tek Yönlü Varyans Analizi (One - Way ANOVA) Sonuçları

\begin{tabular}{llllll}
\hline Varyansın kaynağı & Kareler toplamı & sd & Kareler ortalaması & F & P \\
\hline Gruplar arası & 198.323 & 3 & 66.108 & .485 & .693 \\
Gruplar içi & 33963.764 & 249 & 136.401 & & \\
\hline Toplam & 34162,087 & 252 & & & \\
\hline
\end{tabular}

${ }^{*} \mathrm{p}>05$

Sınıf öğretmeni adaylarının sosyal değerlerinin sınıf seviyelerine göre farklılık gösterip göstermediği yapılan Tek Yönlü Varyans Analizi (One - way ANOVA) Testi ile analiz edilmiştir. Test sonucu sınıf öğretmenlerin sosyal değerlerinin sinıf seviyelerine göre anlamlı düzeyde farklılık göstermediği görülmektedir $(\mathrm{F}=0.485, \mathrm{p}>.05)$. Bu sonuca bakılırsa sınıf öğretmeni adaylarının benzer sosyal değerleri sahip oldukları, sosyal değerlerin sınıf seviyelerine göre değişiklik göstermediği söylenebilir.

\section{Sınıf Öğretmenleri ve Öğretmen Adaylarının Sahip Oldukları Sosyal Değerleri Farklılık Göstermekte midir?}

Tablo 10. Sınıf Öğretmenlerinin ve SınıfÖğretmenleri Adaylarının Sahip Oldukları Sosyal Değerlerinin Farklılı̆̆ına Yönelik Mann-Whitney U Testi Sonuçları

\begin{tabular}{cccccc}
\hline Grup & N & Sira Ortalaması & Sira Toplamı & U & p \\
\hline A Grubu & 343 & 326.82 & 83506.50 & 12407.500 & .086 \\
B Grubu & 253 & 339.95 & 112608.50 & & \\
\hline
\end{tabular}

${ }^{*} \mathrm{p}<.05$

A Grubu= Sınıf Öğretmenleri

B Grubu= Sınıf Öğretmeni Adayları

Sınıf öğretmenlerinin sahip olduğu sosyal değerler ile sınıf öğretmeni adaylarının sahip olduğu sosyal değerleri arasında anlamlı farklılık olup olmadığı yapılan Mann-Whitney U Testi ile analiz edilmiştir. Bu analiz sonucunda sınıf öğretmenlerinin sahip olduğu sosyal değerleri ile sinıf öğretmeni adaylarının sahip olduğu sosyal değerleri arasında anlamlı bir farklılık bulunmamıştır $(U=12407.500)$. Sınıf öğretmenleri sosyal değerleri puan ortalaması ile $\left(\bar{X}_{\mathrm{A}}=326.82\right)$ sinıf öğretmeni adaylarının sosyal değerleri puan ortalaması $\left(\bar{X}_{\mathrm{B}}=339.95\right)$ karşılaştırıldığında sınıf öğretmeni adaylarının sosyal değer puan ortalamalarının yüksek olduğu görülmektedir. $\mathrm{Bu}$ durumda sınıf öğretmeni adaylarının sosyal değerleri, sınıf öğretmenlerine göre anlamlı derecede olmasa bile daha yüksek çıkmıştır denilebilir.

\section{Tartışma, Sonuç ve Öneriler}

Araştırmanın sonucuna göre, sınıf öğretmenlerinin sosyal değerler olarak en çok önemsedikleri konular sırayla şöyledir: "Ailemdeki bireylere büyük önem veririm”, “ Bizi yaratan bir yaratıcı olduğuna inanırım”, "Bilinçli bir seçmen olarak vatandaşlık görevimi yerine getiririm”, 
"Yaptığım işlerde görev bilinci ve sorumluluğuyla hareket ederim”, "Başkalarına iyilikte bulunmaktan hoşlanırım”, "Yaşadığım ortamlarda genel hijyen kurallarına uyarım”, "Bir aileye sahip olmanın gerekliliğini kabul ederim”, "Çalışkan, işe yarar biri olmak benim için önemlidir” ve "İnsanların bana güvenmesi önemlidir". Bu anlamda sınıf öğretmenlerinin sosyal değerler olarak en çok "aile birliğine önem verme, Allah inancı, vatandaşlık görevleri, sorumluluk, iyilikseverlik, temizlik, çalışkanlık ve güven” değerlerine önem verdikleri söylenebilir. Sınıf öğretmenlerinin sosyal değer olarak en düşük puan ortalamaları ise "İspatı mümkün olmayan bilgi ve düşüncelerin güvenilir olmadığına inanırım" ve "Dini inanışlarım hayatta karşılaştı̆̆ım olaylar üzerinde büyük etkiye sahiptir”. Bu anlamda sınıf öğretmenlerinin sosyal değerler olarak "bilimsellik" ve "dini değerler" üzerinde çalışmalar yapılabilir.

Araştırmanın sonucuna göre, sınıf öğretmenlerinin sosyal değerleri cinsiyetlerine göre anlamlı düzeyde farklılık göstermediği belirlenmiştir. Erkek sınıf öğretmenlerinin sahip olduğu sosyal değerler ile kadın sınıf öğretmenlerinin sahip olduğu sosyal değerler benzerdir, aralarında belirgin düzeyde farklılık yoktur denebilir. Memiş ve Güney Gedik (2010)'in araştırmasında ise sınıf öğretmenlerinin önem verdiği değerlerin cinsiyetlerine göre yaşamdan haz alma ve başarı değerleri dışında anlamlı bir farklılık göstermediği belirtilmiştir. Bu anlamda araştırma sonuçlarıyla benzerlik gösterdiği söylenebilir.

Araştırmanın sonucuna göre, sınıf öğretmenlerinin sahip oldukları sosyal değerlerin kıdemlerine göre anlamlı bir farklılık göstermediği bulgusuna ulaşılmıştır. Bu durum, öğretmenlerin okul ortamında aynı ortamı paylaşmaları, benzer sorunlar yaşamaları ve benzer çözümler üretmeleri gibi sebepler göz önüne alındığında, mesleki anlamda daha çok kıdemli olanlarla daha az kıdemli olan öğretmenlerin kaynaştıkları ve birbirlerinden etkilendikleri anlamına gelebilir. Ayrıca sınıf öğretmenlerinin görev süreleri boyunca edindiği deneyimler, sosyal değerleri üzerinde pek de bir değişikliğe sebep olmamıştır, şeklinde de yorumlanabilir. Aktay ve Ekşi (2008)'nin yapmış olduğu araştırmadaki ortaöğretimde görev yapan öğretmenlerin sahip oldukları değerlerin kıdemlerine göre farklılık göstermediği bulgusu araştırma bulgusu ile paralellik göstermektedir.

Araştırmanın sonucuna göre, sınıf öğretmeni adaylarının sosyal değerler olarak en çok önemsedikleri konular sırayla şöyledir: "Bizi yaratan bir yaratıcı olduğuna inanırım”, "Ailemdeki bireylere büyük önem veririm” ve "Başkalarına iyilikte bulunmaktan hoşlanırım”. Bu anlamda "Allah inancı, aile birliğine önem verme ve iyilikseverlik" değerine önem verdikleri söylenebilir. Sınıf öğretmeni adaylarının sosyal değer olarak en düşük puan ortalaması ise "Dini inanışlarım hayatta karşılaştığım olaylar üzerinde büyük etkiye sahiptir”. Bu anlamda sınıf öğretmeni adaylarının sosyal değerler olarak "dini değerler” üzerinde çalışmalar yapılabilir.

Araştırma sonucuna göre, sınıf öğretmeni adaylarının sosyal değerlerinin cinsiyete göre kadın sınıf öğretmen adaylarının lehine anlamlı farklılık gösterdiği bulgusuna ulaşılmıştır. Bu bulguya göre kadın sınıf öğretmeni adaylarının sosyal değerleri, erkek sınıf öğretmeni adaylarına göre anlamlı oranda daha iyi durumdadır denilebilir. Altunay ve Yalçınkaya (2011)'ya göre sınıf, okulöncesi, ortaöğretim fen bilgisi ve ortaöğretim sosyal bilgiler öğretmenliği okuyan öğretmen adaylarının sahip oldukları değerlerin cinsiyete göre farklılık gösterdiği ve bu farklılığın kadın öğretmen adaylarının lehine olduğu belirlenmiştir. Ulaşılan sonuç, araştırmanın sonucuyla benzerlik göstermektedir. 
Araştırma sonucuna göre, sınıf öğretmenlerin sosyal değerlerinin sınıf seviyelerine göre anlamlı düzeyde bir farklılık göstermediği görülmektedir. Bu durumda, sınıf öğretmeni adaylarının öğrenim gördükleri seviyelerin ve ders sayısının artmasının sosyal değerleri üzerinde anlamlı derecede etki etmediği şeklinde yorumlanabilir.

Araştırma sonucuna göre, sınıf öğretmenlerinin sosyal değerleri puan ortalaması ile sınıf öğretmeni adaylarının sosyal değerleri puan ortalaması karşılaştırıldığında sınıf öğretmeni adaylarının sosyal değer puan ortalamalarının daha yüksek olduğu görülse de bu farklılık anlamlı değildir. Değerler ve sosyal değerlere yönelik olarak bu çalışmadan elde edilen bulgulara göre ileride yapılacak çalışmalara ve uygulamalara yönelik aşağıdaki öneriler verilebilir:

1. Sınıf öğretmenlerinin sosyal değerlerine yönelik "bilimsellik" ve "dini değerleri” üzerine çalışmalar yapılabilir.

2. Sınıf öğretmeni adaylarının sosyal değerlerine ilişkin "dini değerleri” üzerinde çalışmalar yapilabilir.

3. Branşları fark etmeksizin tüm öğretmenler ve tüm öğretmen adaylarının sosyal değerleri üzerinde karşılaştırmalı araştırmalar yapılabilir.

4. Sosyal değerler üzerine ilkokul, ortaokul ve lise öğrencileri üzerinde de karşılaştırmalı araştırmalar yapılabilir.

\section{Kaynakça}

Acat, M. B., Aslan, M. (2012). Yeni bir değer sınıflaması ve bu sınıflamaya bağlı olarak öğrencilere kazandırılması gereken değerler. Kuram ve Uygulamada Eğitim Bilimleri (KUYEB), 12(2), 1460-1474

Akbaş, O. (2004). Türk milli eğitim sisteminin duyuşsal amaçlarının ilköğretim II. kademedeki gerçekleşme derecesinin değerlendirilmesi (Yayımlanmamış doktora tezi), Gazi Üniversitesi Eğitim Bilimleri Enstitüsü, Ankara.

Aktay, A., Ekşi, H. (2008). Yönetici ve öğretmenlerin değer tercihleri ile örgütsel vatandaşlık davranışları arasındaki ilişki. İş Ahlakı Dergisi, 3(2), 19-65

Aktepe, V. (2014). Farkl yönleriyle değerler eğitimi. Refik Turan ve Kadir Ulusoy (Ed.) kitabının içinde, Ailede değerler eğitimi ve program ihtiyacı (s.77-94), Ankara: Pegem Akademi. 
Aktepe, V. , Gündüz, M. (2018). Özel öğretim yöntemleri. Abdulkadir Uzunöz ve Vedat Aktepe (Ed.) kitabının içinde, Değerler Eğitimi (s.71-103), Ankara: Pegem Akademi.

Aktepe, V., Tahiroğlu, M. (2016). Değerler eğitimi yaklaşımları ve etkinlik örnekleri. The Journal of Academic Social Science Studies, 42(III), 361-384.

Aktepe, V., Yel, S. (2009). İlköğretim öğretmenlerinin değer yargılarının betimlenmesi: Kırşehir ili örneği. Türk Eğitim Bilimleri Dergisi, 7(3), 607-622.

Akbaba Altun, S. (2003). Eğitim yönetimi ve değerler. Değerler Eğitimi Dergisi, 1(1), 7-18.

Altunay, E., Yalçınkaya, M. (2011). Öğretmen adaylarının bilgi toplumunda değerlere ilişkin görüşlerinin bazı değişkenler açısından incelenmesi. Kuram ve Uygulamada Eğitim Yönetimi, 1(1), 5-28.

Bolat, Y. (2013). Bir değer ölçme aracı: Çok boyutlu sosyal değerler ölçeği. Turkish Journal of Education, 2(4), 13-27.

Budumlu Akkiprik, G. (2007). Genel lise öğretmenlerine göre karakter eğitim yoluyla öğrencilere kazandırılacak değerler: Çok boyutlu bir araştırma (Yayımlanmamış yüksek lisans tezi). Yedi Tepe Üniversitesi Eğitim Bilimleri Enstitüsü, İstanbul.

Büyüköztürk, Ş., Çakmak, E., Akgün, Ö., Karadeniz, Ş., ve Demirel, F. (2016). Bilimsel araştırma yöntemleri. Ankara: Pegem Akademi.

Dilmaç B., Ekşi, H. (2007). Değerler eğitimi: Temel tartışmalar ve yaklaşımlar. İlköğretmen Dergisi, 14, 21-29

Düzgün, Ş. (2007). İnsan onuru ve toplumsal yaşam için etik. KADER Kelam Araştırmaları Dergisi, 5(1), 1-12.

Gökdere, M., Çepni, S. (2011). Üstün yetenekli çocuklara verilen değerler eğitiminde öğretmenin rolü. Değerler Eğitimi Dergisi, 1(2), 93-107.

Göz, K. (2016). Birlikte yaşama kültürü açısından Hılfu'l-Fudûl. Bozok Üniversitesi İlahiyat Fakültesi Dergisi, 10(10), 111-126.

Güngör, E. (1998). Değerler psikolojisi üzerine araştırmalar. İstanbul: Ötüken.

Katılmış, A. ve Balcı, A. (2017). Coğrafya öğretmeni adaylarının değerler eğitimine yönelik görüşlerinin incelenmesi. Marmara Coğrafya Dergisi, 35, 1-12. 
MEB (2005). İlköğretim sosyal bilgiler dersi 4. sınıföğretim programı ve kılavuzu. Ankara: MEB

MEB (2010). MEB Talim ve Terbiye Kurulu Başkanlığı (2010/53 Sayılı Genelge).

MEB (2020). Değerler eğitimi yönergesi, Uygulama İlke ve Esasları (İkinci bölüm). Erişim adresi: http://mebk12.meb.gov.tr/meb_iys_dosyalar/34/39/749197/dosyalar/2015_02/ 09093609.pdf

Memiş, A. ve Güney Gedik, E. (2010). Sınıf öğretmenlerinin değer yönelimleri. Değerler Eğitimi Dergisi, 8(20), 123-142.

Naylor, D, T. and Diem, R. (1987). Elementary and middle school social studies. New York: Random House.

Özmen, C., Er, H. ve Gürgil, F. (2012). İlköğretim branş öğretmenlerinin değerler eğitimine ilişkin görüşleri üzerine bir araştırma. Mustafa Kemal Üniversitesi Sosyal Bilimler Enstitüsü Dergisi, 9(17), 297-311.

Sarı, O. (2013). Sosyal değerler emek ve sosyal edebiyata dair bazı düşünceler. FSM İlmî Araştırmalar İnsan ve Toplum Bilimleri Dergisi, 2(Güz), 201-227.

Şen, Ü. (2007). Millî Eğitim Bakanlığının 2005 yılında tavsiye ettiği 100 Temel Eser yoluyla Türkçe eğitiminde değerler öğretimi üzerine bir araştırma (Yayımlanmamış yüksek lisans tezi). Gazi Üniversitesi Eğitim Bilimleri Enstitüsü, Ankara.

Tezcan, M. (2018). Değerler eğitimi sosyolojik yaklaşım, Ankara: Anı.

TDK (2011). Türk Dil Kurumu Türkçe sözlük (11.Baskı), Ankara.

Tonga, D. (2017). Rol model olarak sosyal bilgiler öğretmeni. Kırıkkale Üniversitesi Sosyal Bilimler Dergisi, 7(2), 17-30.

Turan, S., ve Aktan, D. (2008). Okul hayatında var olan ve olması düşünülen sosyal değerler. Türk Eğitim Bilimleri Dergisi, 6(2), 227-259

Ulusoy, K. ve Arslan, A. (2014). Farklı yönleriyle değerler Eğitimi, Refik Turan ve Kadir Ulusoy (Ed.) kitabının içinde, Değerli bir kavram olarak değer ve değerler eğitimi (s.2-15), Ankara: Pegem Akademi.

Ulusoy, K. ve Dilmaç, B. (2016). Değerler eğitimi. Ankara: Pegem Akademi. 
UNESCO, (2002). Framework for action on values education in early childhood. Reports Descriptive, Multilingual/Bilingual Materials. Erişim adresi. http://unesdoc.unesco.org/ images/0012/001287/128712e.pdf

Yazıcı, M. (2014). Değerler ve toplumsal yapıda sosyal değerlerin yeri. Fırat Üniversitesi Sosyal Bilimler Dergisi, 24(1), 209-223.

Yontar, A. (2019). Karakter ve değer eğitimi. Vedat Aktepe ve Mevlüt Gündüz (Ed.) kitabının içinde, Değerlerin kaynă̆g ve toplumsal, kültürel, dini, ahlaki değerleri (s.92-107), Ankara: Pegem Akademi. 